\title{
Monogenic forms of systemic lupus erythematosus: new insights into SLE pathogenesis
}

\author{
Alexandre Belot ${ }^{*}$ and Rolando Cimaz ${ }^{2}$
}

\begin{abstract}
The pathogenesis of Systemic Lupus Erythematosus (SLE) is complex and remains poorly understood. Infectious triggers, genetic background, immunological abnormalities and environmental factors are all supposed to interact for the disease development. Familial SLE as well as early-onset juvenile SLE studies make it possible to identify monogenic causes of SLE. Identification of these rare inherited conditions is of great interest to understand both SLE pathogenesis and molecular human tolerance mechanisms. Complement deficiencies, genetic overproduction of interferon- $a$ and apoptosis defects are the main situations that can lead to monogenic SLE.

Here, we review the different genes involved in monogenic SLE and highlight their importance in SLE pathogenesis.
\end{abstract}

Keywords: SLE genetics, Mendelian, Complement deficiency, Interferon-alpha, Pediatrics

Systemic lupus erythematosus (SLE) is a complex disease: environmental factors (e.g. infections), immunological defects (responsible for tolerance breakdown), and genetic factors (mostly thought to be polygenic and associated to genetic polymorphism [1,2]) all play a role in its development. Rarely, lupus can be secondary to single gene mutations; we summarize recently discovered monogenic forms of lupus, and highlight the impact of these gene mutations on SLE pathogenesis.

\section{Review \\ Complement defects: apoptotic cell and immune complexes clearance deficiency}

Primary complement defects, especially in early components of the classical pathway, can lead to an increased susceptibility to SLE [3]. However, less than 1\% of SLE cases are associated with complement deficiencies, and conversely complement deficiencies are not always associated to SLE [4]. C1q, C1s and C1r complete deficiencies are rare and associated with a high risk to develop pediatric SLE (estimated to $93 \%$ for C1q and 66\% for

\footnotetext{
* Correspondence: alexbelot@yahoo.fr

${ }^{1}$ Pediatric nephrology and rheumatology Unit, Hôpital Femme Mère Enfant, Lyon, Bron, Université de Lyon, Lyon CNRS UMR5239, France Full list of author information is available at the end of the article
}

$\mathrm{C} 1 \mathrm{~s} / \mathrm{r})$. C1q deficiency is associated with cutaneous rash in $90 \%$ of case and glomerulonopehritis in around $1 / 3$ of cases [5]. Notably, the incidence of anti-doublestranded DNA antibodies "(anti-dsDNA)"is low. C4 deficiency is also strongly associated with SLE development (around 75\%) [6-8] (Table 1). Homozygous C2 deficiency, which is the most frequent hereditary deficiency in classical pathway complement components $(1 / 10,000$ to $1 / 30,000$ among caucasians), is associated with SLE in only 10 to $30 \%$ of the cases, suggesting that exogenous factors may be also involved. In all cases, early-onset disease and association with recurrent pyogenic or neisserial infections should evoke the diagnosis.

Complement deficiencies demonstrate the crucial role of complement in maintenance of tolerance (Figure 1). Early components of the classical pathway (especially C1q) help clearing apoptotic cells, thus decreasing the number of autoantigens [9]. Another role of complement is to process antibodies and eliminate circulating immune complexes, thus decreasing or avoiding vascular deposition. Interestingly, complement plays a role in $\mathrm{T}$ and $\mathrm{B}$ cell activation as well, and complement deficiency may upset the balance of lymphoid cell activation[10]. Finally, $\mathrm{C} 1 \mathrm{q}$ has also been shown to inhibit in vitro interferon IFN- $\alpha$ production by plasmacytoid dendritic

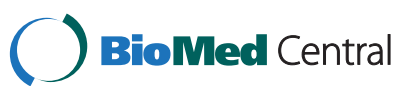


Table 1 Complement deficiencies

\begin{tabular}{lllll}
\hline $\begin{array}{l}\text { Complement } \\
\text { deficiency }\end{array}$ & Locus & $\begin{array}{l}\text { Inheritance } \\
\text { pattern }\end{array}$ & Clinical manifestations & Infection susceptibility \\
\hline C1q & $1 p 36.3-p 34.1$ & $A R$ & Nephritis, CNS involvement, photosensitivity & Encapsulated bacteria \\
\hline C1r/C1s & $12 p 13$ & AR & Nephritis & Encapsulated bacteria \\
\hline C4 & $6 p 21.3$ & $A R$ & Multiorgan involvement; glomerulonephritis & Encapsulated bacteria \\
\hline C2 & $6 p 21.3$ & $A R$ & $\begin{array}{l}\text { Photosensitivity and articular involvement; } \\
\text { mild or absent renal, neurological or } \\
\text { pleuropericardial involvement }\end{array}$ & $\begin{array}{l}\text { Pyogenic infections; encapsulated bacteria; } \\
\text { Streptococcus pneumoniae sepsis and } \\
\text { meningitis }\end{array}$ \\
\hline C3 & $19 q 13$ & AR & $\begin{array}{l}\text { Malar rash, photosensitivity, arthralgia and } \\
\text { Raynaud's phenomenon }\end{array}$ & Recurrent pyogenic infections \\
\hline C5-C9: MAC & $\begin{array}{l}\text { C5/9p34.1, C6-C7/5p13, } \\
\text { C8A-C8B/1p32,C8G/9, }\end{array}$ & AR & Multiorgan involvement & Neisserial infections \\
& C9/5p13 & & \\
\hline
\end{tabular}

cells [11], and its deficiency can lead to defective suppression of IFN- $\alpha$ in response to immune complexcontaining nucleoproteins [12].

\section{Apoptosis defects}

Apoptosis defects are thought to be involved in SLE pathogenesis as autoreactive B and/or T cells might survive death signals when they are ongoing central or peripheral tolerance. Nevertheless, to date there is no evidence that apoptosis-related gene defects involving $\mathrm{B}$ or $\mathrm{T}$ cell tolerance are directly involved in the pathogenesis of SLE. Autoimmune lymphoproliferative syndrome (ALPS) is the human counterpart of the lpr mouse, a widely explored model of murine lupus. Molecular mechanisms of ALPS are related to deficiencies of T cell apoptosis. Mutations in the Fas/FasL pathway underlie

\section{Learning from monogenic SLE:}

TREX-1 mutation:

intracytoplasmic DNA accumulation trigger IFNa production

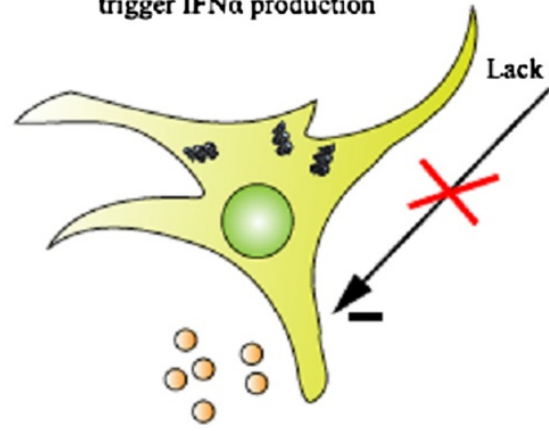

IFN $\alpha$

$0_{0}^{\circ}$

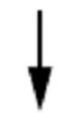

-Cytoplasmic DNA can promote IFN $\alpha$ production -High level of IFN $\alpha$ is associated with autoimmunity
Complement deficiency:

Classical pathway defects induce increase of apoptotic bodies and circulating immune complexes (CIC) Lack of regulatory functions of $\mathrm{Cl}$ q on IFN $\alpha$ production
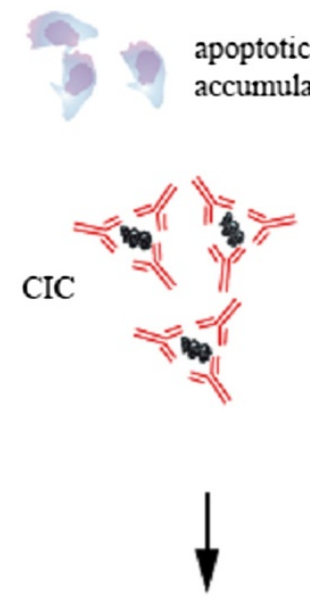

-Complement is a major regulator of apoptotic bodies and CIC clearance -Increased level of apoptotic bodies and CIC is associated with SLE
FasL deficiency:

Apoptosis defects induce activated $T$ cells persistance
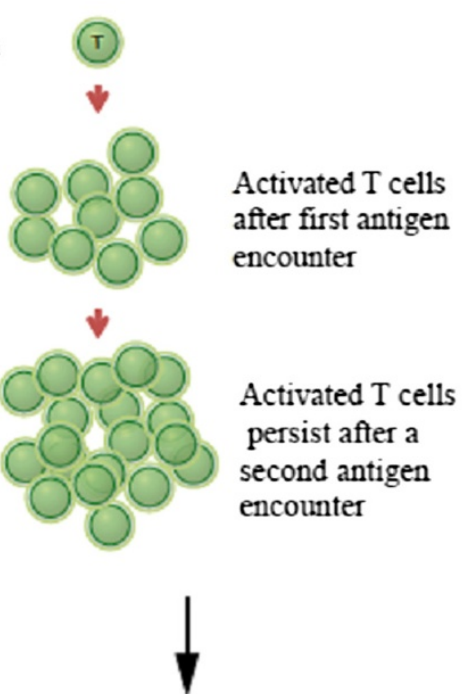

-Activation induced cell death defects promote autoimmunity

Figure 1 Schematic views of monogenic SLE pathogenesis. 
ALPS, which is characterized by lymphoproliferation in lymphoid organs associated with multiple autoimmunity [13]. One single case has been reported with classical features of SLE [14].

\section{Interferon (IFN)-a hyperproduction}

Genomic approaches have shown that human SLE leukocytes homogeneously express type I interferon (IFN)induced transcripts [15]. In addition, large-scale genetic analyses have demonstrated that genes involved in IFNa pathway such as IRF5, IRF7 both expressed downstream of the endosomal TLR or STAT-4, transcriptional factor induced by Interferon type I were associated with SLE [16]. In the last years, studies on early-onset SLE and familial SLE led to the identification of new genes involved in IFN- $\alpha$ production (Table 2). This all started with the identification of the genes responsible for Aicardi-Goutieres syndrome (AGS) [17]. AGS is a rare genetic disorder occurring within the first few weeks of life that can mimic maternofetal infections, with an inflammatory encephalopathy. This autosomal recessive disease is associated with high IFN- $\alpha$ production [18]. Some children with AGS develop an early-onset form of SLE $[19,20]$.

Nucleic acid are able to initiate an immune response, activating membrane receptors such as Toll-like receptors (TLR) or cytosolic sensors, involved in IFN- $\alpha$ production [21]. Defective clearance of self-derived nucleic acids can cause severe IFN-associated autoimmunity (Figure 1). One major mechanism by which these extracellular nucleic acids cause autoimmunity is through activation of TLR7 and TLR9 on autoreactive B cells $[22,23]$. Recently, it has been shown that TREX1 deficiency results in endogenous DNA accumulation and IFN- $\alpha$ production, independently from TLRs [24].

\section{Rare cases of nuclease defects are responsible for monogenic lupus}

DNAse type III, also called TREX1, is the main 3'5'DNA exonuclease and has been shown to downregulate IFN-stimulatory DNA response [24]. TREX1 knockout mouse develop an inflammatory cardiopathy [25]. Interestingly, TREX1 deficiency is responsible for intracellular DNA accumulation and TLR independent-
IFN- $\alpha$ production[24]. TREX1 mutations in humans lead to Aicardi-Goutieres syndrome, chilblain lupus and represent the more common cause of monogenic lupus. Indeed, systematic TREX1 mutation screening in adult lupus patients revealed 0.5 to $2 \%$ heterozygosity, thus making TREX1 mutations the most frequent form of monogenic lupus $[26,27]$.

\section{Other gene involved in Aicardi Goutières syndrome}

SAMHD1 is a protein, encoded by AGS5, that is upregulated in response to viral infections and may have a regulator role on immune system and cerebral vascular homeostasis $[28,29]$. One case of chillblain lupus in a 3year-old boy with epilepsy was first diagnosed with a mutation in AGS5 gene [30]. Two additional cases have been reported with typical chillblain lupus, without central nervous system involvement [31]. AGS5 mutations can be associated with arthritis, chronic ulcers, mental retardation and microcephaly. Plasmatic IFN- $\alpha$ is increased, even though SAMHD1 deficiency has not yet been directly linked to IFN overproduction.

\section{Spondyloenchondrodysplasia (SPENCD)}

$A C P 5$ is another gene, encoding tartrate-resistant acid phosphatase (TRAP), that has been associated to an immuno-osseous disease: the spondyloenchondrodysplasia (SPENCD). This syndrome is associated with platispondily, growth retardation and enchondromatosis. Various immunological findings have been reported including typical SLE with malar rash, lupus nephritis, antiphospholipid syndrome and anti-dsDNA [32]. Osseous anomalies can be subtle. TRAP is expressed in bone and in immune cells (mainly osteoclasts and dendritic cells) and is involved in bone resorption, even though its precise physiological role remains to be defined. Osteopontin (OPN, a substrate of TRAP) is a bone matrix protein involved in osteoclast adhesion and migration, and is dephosphorylated by TRAP $[33,34]$. In TRAPdeficient mice, OPN accumulates both around osteoclasts and in intracellular vacuoles, suggesting that TRAP is required for processing and/or degradation of OPN [16]. Interestingly, OPN accumulates in serum, urine and cells cultured from TRAP-deficient individuals and patients' dendritic cells exhibit an altered cytokine

Table 2 Main features of mendelian SLE

\begin{tabular}{llll}
\hline Gene mutated/protein & Chromosome & Inheritance & Clinical features \\
\hline TREX1/TREX1 & $3 \mathrm{p} 21$ & $\mathrm{AD}$ & Chilblain lupus, intracerebral calcifications \\
\hline DNAse //DNase I & $16 \mathrm{p} 13$ & $\mathrm{AD}$ & Systemic lupus, Sjögren syndrome,high levels of antinucleosomal antibodies \\
\hline DNAse IL3/DNase1L3 & $3 \mathrm{p} 14$ & $\mathrm{AR}$ & Early-onset SLE, antinuclear antibodies, anti-dsDNA, ANCA \\
\hline AGS5/SAMHD1 & $20 \mathrm{q} 11$ & $\mathrm{AD}$ & Chilblain lupus, intracerebral calcifications, mental retardation \\
\hline ACP5/TRAP & $19 \mathrm{p} 13$ & $\mathrm{AR}$ & $\begin{array}{l}\text { Growth retardation, spondyloenchondrodysplasia, SLE, Sjögren, vitiligo, } \\
\text { myositis, Raynaud, ANA, anti-dsDNA }\end{array}$ \\
\hline
\end{tabular}


profile, and are more potent than control cells in stimulating allogeneic $\mathrm{T}$ cell proliferation in mixed lymphocyte reactions [35]. OPN and IFN- $\alpha$ levels are both elevated in lupus patient's sera and seems correlated [36]. In mouse, OPN is essential for IFN- $\alpha$ production, downstream of the Toll-like-receptor 9 in plasmacytoïd dendritic cells [37]. Taken together, TRAP deficiency may drive an inflammatory T cell response and promote IFN- $\alpha$ production in human.

\section{DNASE1/DNASE1L3 mutation}

DNAse type I is a widespread endonuclease that can be found in blood and urine. DNase1 deficiency in mouse induces the presence of ANA and the deposition of immune complexes in glomeruli [38]. Two unrelated cases of juvenile SLE were reported with a mutation in DNAse type 1 [39], and exhibited very high levels of antinucleosomal antibodies. This variant represent a very rare cause of lupus and further exploration in a large UK Cohort of 170 SLE patients did not found any mutation [40]. Recently, a group from Saudi Arabia has identified $D N A S E 1 L 3$ as a new gene mutated in familial cases of juvenile SLE [41]. Mutated patients presented with association of anti-nuclear antibody, anti-dsDNA and ANCA. The link to SLE pathogenesis is unknown, but may be (as in TREX1 mutations) related to DNA accumulation, thus triggering IFN- $\alpha$ production.

\section{Chronic granulomatous disease (CGD)}

CGD is characterized by recurrent life-threatening infections by bacteria and fungi, due to severely impaired phagocyte intracellular destruction. CGD is caused by defects of NADPH (nicotinamide adenine dinucleotide phosphate) oxidase system, which is responsible for the generation of superoxide and other reactive oxygen species in phagocytic cells. The X-linked form, caused by mutations of the $C Y B B$ gene, accounts for more than $75 \%$ of the cases [42]. In the large U.S. series of 368 CGD patients, ten $(2.7 \%)$ affected patients presented concomitantly discoid lupus (DLE) and 2 (0.5\%) SLE. A large number of first-degree female relatives were also reported as having SLE or discoid lupus, while infection susceptibility was not increased. Cale et al. [43] investigated 19 mothers who carried the X-linked CGD allele for the presence of lupus manifestations. Remarkably, 12 of them presented photosensitivity, seven arthralgia, and eight had mouth ulcers. Anti-nuclear antibodies were positive in five, one had anti-dsDNA and another a lupus anticoagulant. The link between CYBB mutation and lupus may arise from the apoptosis defect of neutrophils in CGD patients, characterized by an impaired exposure of phosphatidyl serine on neutrophil membrane [44]. Moreover, in CGD neutrophil apoptosis is associated to diminished production of anti-inflammatory mediators [5]. Of note, neutrophils are now have been shown to be important in lupus pathogenesis, especially since mature SLE neutrophils are primed in vivo by type I IFN and die upon exposure to SLE-derived anti-ribonucleoprotein antibodies, releasing neutrophil extracellular traps (NETs) which contain DNA as well as large amounts of proteins that facilitate the uptake and recognition of mammalian DNA by plasmacytoid dendritic cells [45]. Indeed, SLE NETs activate pDCs to produce high levels of IFN- $\alpha$ in a DNA- and Toll-like receptor 9-dependent manner.

Altogether, these data might suggest that $\mathrm{CYBB}$ and other CGD-related genes could be lupus-susceptibility genes.

\section{Conclusions}

Early onset lupus, familial lupus and syndromic lupus are rare situations that can lead to the identification of a unique gene responsible for the disease. Identification of this monogenic susceptibility to lupus can help to understand both lupus pathogenesis and tolerance breakdown in human immunology. To date, complement system deficiency, apoptosis defects and interferon overproduction have been confirmed as responsible for susceptibility to lupus. New genetic techniques such as exome sequencing could help to discover new genes and give insights in understanding SLE pathogenesis as well as molecular mechanisms of tolerance maintenance.

\section{Abbreviations}

AGS: Aicardi-Goutieres syndrome; CGD: Chronic granulomatous disease; IFN: Interferon; NETs: Neutrophil extracellular traps; SLE: Systemic lupus erythematosus; SPENCD: Spondyloenchondrodysplasia; TLR: Toll-like receptor.

\section{Competing interests}

The authors declare that they have no competing interest.

\section{Authors' contributions}

$A B$ and $R C$ elaborated the draft and wrote the paper. Both authors read and approved the final manuscript.

\section{Acknowledgments}

This work has been supported by grants from Hospices Civils de Lyon and Institut National de la Santé et de la Recherche Médicale.

\section{Author details}

${ }^{1}$ Pediatric nephrology and rheumatology Unit, Hôpital Femme Mère Enfant, Lyon, Bron, Université de Lyon, Lyon CNRS UMR5239, France. ${ }^{2}$ Rheumatology Unit, Anna Meyer Children's Hospital, University of Florence, Florence, Italy.

Received: 26 March 2012 Accepted: 29 July 2012

Published: 10 August 2012

\section{References}

1. Namjou B, Kilpatrick J, Harley JB: Genetics of clinical expression in SLE. Autoimmunity 2007, 40:602-612.

2. Hom G, Graham RR, Modrek B, Taylor KE, Ortmann W, Garnier S, Lee AT, Chung SA, Ferreira RC, Pant PV, et al: Association of systemic lupus erythematosus with C8orf13-BLK and ITGAM-ITGAX. N Engl J Med 2008, 358:900-909.

3. Bussone $G$, Mouthon $L$ : Autoimmune manifestations in primary immune deficiencies. Autoimmun Rev 2009, 8:332-336. 
4. Manderson AP, Botto M, Walport MJ: The role of complement in the development of systemic lupus erythematosus. Annu Rev Immunol 2004 22:431-456.

5. Ritterhouse LL, Crowe SR, Niewold TB, Merrill JT, Roberts VC, Dedeke AB, Neas BR, Thompson LF, Guthridge JM, James JA: B lymphocyte stimulator levels in systemic lupus erythematosus: higher circulating levels in African American patients and increased production after influenza vaccination in patients with low baseline levels. Arthritis Rheum 2011, 63:3931-3941

6. Pickering MC, Botto M, Taylor PR, Lachmann PJ, Walport MJ: Systemic lupus erythematosus, complement deficiency, and apoptosis. Adv Immunol 2000, 76:227-324.

7. Sullivan KE: Complement deficiency and autoimmunity. Curr Opin Pediatr 1998, 10:600-606.

8. Arason GJ, Jorgensen GH, Ludviksson BR: Primary immunodeficiency and autoimmunity: lessons from human diseases. Scand J Immunol 2010, 71:317-328.

9. Botto M, Dell'Agnola C, Bygrave AE, Thompson EM, Cook HT, Petry F, Loos M, Pandolfi PP, Walport MJ: Homozygous C1q deficiency causes glomerulonephritis associated with multiple apoptotic bodies. Nat Genet 1998, 19:56-59.

10. Kemper C, Chan AC, Green JM, Brett KA, Murphy KM, Atkinson JP: Activation of human CD4+ cells with CD3 and CD46 induces a Tregulatory cell 1 phenotype. Nature 2003, 421:388-392.

11. Niewold TB, Wu SC, Smith M, Morgan GA, Pachman LM: Familial aggregation of autoimmune disease in juvenile dermatomyositis. Pediatrics 2011, 127:e1239-e1246.

12. Pothlichet J, Niewold TB, Vitour D, Solhonne B, Crow MK, Si-Tahar M: A lossof-function variant of the antiviral molecule MAVS is associated with a subset of systemic lupus patients. EMBO molecular medicine 2011, 3:142-152.

13. Rieux-Laucat F, Le Deist F, Hivroz C, Roberts IA, Debatin KM, Fischer A, de Villartay JP: Mutations in Fas associated with human lymphoproliferative syndrome and autoimmunity. Science 1995, 268:1347-1349.

14. Wu J, Wilson J, He J, Xiang L, Schur PH, Mountz JD: Fas ligand mutation in a patient with systemic lupus erythematosus and lymphoproliferative disease. J Clin Invest 1996, 98:1107-1113.

15. Bennett L, Palucka AK, Arce E, Cantrell V, Borvak J, Banchereau J, Pascual V: Interferon and granulopoiesis signatures in systemic lupus erythematosus blood. J Exp Med 2003, 197:711-723.

16. Niewold TB: Interferon alpha as a primary pathogenic factor in human lupus. Journal of interferon \& cytokine research: the official journal of the International Society for Interferon and Cytokine Research 2011, 31:887-892.

17. Crow YJ, Rehwinkel J: Aicardi-Goutieres syndrome and related phenotypes: linking nucleic acid metabolism with autoimmunity. Hum Mol Genet 2009, 18:R130-R136.

18. Dussaix E, Lebon P, Ponsot G, Huault G, Tardieu M: Intrathecal synthesis of different alpha-interferons in patients with various neurological diseases. Acta Neurol Scand 1985, 71:504-509.

19. Aicardi J, Goutieres F: Systemic lupus erythematosus or Aicardi-Goutieres syndrome? Neuropediatrics 2000, 31:113.

20. Dale RC, Tang SP, Heckmatt JZ, Tatnall FM: Familial systemic lupus erythematosus and congenital infection-like syndrome. Neuropediatrics 2000, 31:155-158.

21. Koyama S, Ishii KJ, Kumar H, Tanimoto T, Coban C, Uematsu S, Kawai T, Akira S: Differential role of TLR- and RLR-signaling in the immune responses to influenza A virus infection and vaccination. J Immuno/ 2007 179:4711-4720.

22. Leadbetter EA, Rifkin IR, Hohlbaum AM, Beaudette BC, Shlomchik MJ Marshak-Rothstein A: Chromatin-lgG complexes activate B cells by dual engagement of IgM and Toll-like receptors. Nature 2002, 416:603-607.

23. Christensen SR, Shupe J, Nickerson K, Kashgarian M, Flavell RA, Shlomchik MJ: Toll-like receptor 7 and TLR9 dictate autoantibody specificity and have opposing inflammatory and regulatory roles in a murine model of lupus. Immunity 2006, 25:417-428.

24. Stetson DB, Ko JS, Heidmann T, Medzhitov R: Trex1 prevents cell-intrinsic initiation of autoimmunity. Cell 2008, 134:587-598.

25. Morita M, Stamp G, Robins P, Dulic A, Rosewell I, Hrivnak G, Daly G, Lindah T, Barnes DE: Gene-targeted mice lacking the Trex1 (DNase III) 3'- > 5' DNA exonuclease develop inflammatory myocarditis. Mol Cell Biol 2004, 24:6719-6727.
26. Lee-Kirsch MA, Gong M, Chowdhury D, Senenko L, Engel K, Lee YA, de Silva $U$, Bailey SL, Witte T, Vyse TJ, et al: Mutations in the gene encoding the 3'5' DNA exonuclease TREX1 are associated with systemic lupus erythematosus. Nat Genet 2007, 39:1065-1067.

27. Namjou B, Kothari PH, Kelly JA, Glenn SB, Ojwang JO, Adler A, AlarconRiquelme ME, Gallant CJ, Boackle SA, Criswell LA, et al: Evaluation of the TREX1 gene in a large multi-ancestral lupus cohort. Genes Immun 2011, $12: 270-279$.

28. Zhao D, Peng D, Li L, Zhang Q, Zhang C: Inhibition of G1P3 expression found in the differential display study on respiratory syncytial virus infection. Virol J 2008, 5:114.

29. Xin B, Jones S, Puffenberger EG, Hinze C, Bright A, Tan H, Zhou A, Wu G, Vargus-Adams J, Agamanolis D, Wang H: Homozygous mutation in SAMHD1 gene causes cerebral vasculopathy and early onset stroke. Proc Natl Acad Sci U S A 2011, 108:5372-5377.

30. Abdel-Salam GM, El-Kamah GY, Rice GI, El-Darouti M, Gornall H, Szynkiewicz M, Aymard F, Zaki MS, Abdel-Aleem AK, Lebon P, Crow YJ: Chilblains as a diagnostic sign of aicardi-goutieres syndrome. Neuropediatrics 2010, 41:18-23.

31. Ravenscroft JC, Suri M, Rice Gl, Szynkiewicz M, Crow YJ: Autosomal dominant inheritance of a heterozygous mutation in SAMHD1 causing familial chilblain lupus. Am J Med Genet A 2011, 155A:235-237.

32. Briggs TA, Rice Gl, Daly S, Urquhart J, Gornall H, Bader-Meunier B, Baskar K, Baskar S, Baudouin V, Beresford MW, et al: Tartrate-resistant acid phosphatase deficiency causes a bone dysplasia with autoimmunity and a type I interferon expression signature. Nat Genet 2011, 43:127-131

33. Agik S, Franek BS, Kumar AA, Kumabe M, Utset TO, Mikolaitis RA, Jolly M, Niewold TB: The autoimmune disease risk allele of UBE2L3 in African American patients with systemic lupus erythematosus: a recessive effect upon subphenotypes. J Rheumatol 2012, 39:73-78.

34. Feng X, Reder NP, Yanamandala M, Hill A, Franek BS, Niewold TB, Reder AT, Javed A: Type I interferon signature is high in lupus and neuromyelitis optica but low in multiple sclerosis. J Neurol Sci 2012, 313:48-53.

35. Lausch E, Janecke A, Bros M, Trojandt S, Alanay Y, De Laet C, Hubner CA, Meinecke P, Nishimura G, Matsuo M, et al: Genetic deficiency of tartrate-resistant acid phosphatase associated with skeletal dysplasia, cerebral calcifications and autoimmunity. Nat Genet 2011, 43:132-137.

36. Kariuki SN, Moore JG, Kirou KA, Crow MK, Utset TO, Niewold TB: Age- and gender-specific modulation of serum osteopontin and interferon-alpha by osteopontin genotype in systemic lupus erythematosus. Genes Immun 2009, 10:487-494.

37. Shinohara ML, Lu L, Bu J, Werneck MB, Kobayashi KS, Glimcher LH, Cantor H: Osteopontin expression is essential for interferon-alpha production by plasmacytoid dendritic cells. Nat Immunol 2006, 7:498-506.

38. Napirei M, Karsunky H, Zevnik B, Stephan H, Mannherz HG, Moroy T: Features of systemic lupus erythematosus in Dnase1-deficient mice. Nat Genet 2000, 25:177-181.

39. Yasutomo K, Horiuchi T, Kagami S, Tsukamoto H, Hashimura C, Urushihara M, Kuroda Y: Mutation of DNASE1 in people with systemic lupus erythematosus. Nat Genet 2001, 28:313-314.

40. Simmonds MJ, Heward JM, Kelly MA, Allahabadia A, Foxall H, Gordon C, Franklyn JA, Gough SC: A nonsense mutation in exon 2 of the DNase I gene is not present in UK subjects with systemic lupus erythematosus and Graves' disease: Comment on the article by Rood et al. Arthritis Rheum 2002, 46:3109-3110

41. Al-Mayouf SM, Sunker A, Abdwani R, Abrawi SA, Almurshedi F, Alhashmi N, Al Sonbul A, Sewairi W, Qari A, Abdallah E, et al: Loss-of-function variant in DNASE1L3 causes a familial form of systemic lupus erythematosus. Nat Genet 2011, 43:1186-1188.

42. Winkelstein JA, Marino MC, Johnston RB Jr, Boyle J, Curnutte J, Gallin tل Malech HL, Holland SM, Ochs H, Quie P, et al: Chronic granulomatous disease. Report on a national registry of 368 patients. Medicine 2000 79:155-169.

43. Sweiss NJ, Zhang W, Franek BS, Kariuki SN, Moller DR, Patterson KC, Bennett $P$, Girijala LR, Nair V, Baughman RP, et al: Linkage of type I interferon activity and TNF-alpha levels in serum with sarcoidosis manifestations and ancestry. PLoS One 2011, 6:e29126.

44. Niewold TB, Kelly JA, Kariuki SN, Franek BS, Kumar AA, Kaufman KM, Thomas K, Walker D, Kamp S, Frost JM, et al: IRF5 haplotypes demonstrate diverse 
serological associations which predict serum interferon alpha activity and explain the majority of the genetic association with systemic lupus erythematosus. Ann Rheum Dis 2012, 71:463-468.

45. Garcia-Romo GS, Caielli S, Vega B, Connolly J, Allantaz F, Xu Z, Punaro M, Baisch J, Guiducci C, Coffman RL, et al: Netting neutrophils are major inducers of type I IFN production in pediatric systemic lupus erythematosus. Science translational medicine 2011, 3:73ra20.

doi:10.1186/1546-0096-10-21

Cite this article as: Belot and Cimaz: Monogenic forms of systemic lupus erythematosus: new insights into SLE pathogenesis. Pediatric

Rheumatology 2012 10:21.

\section{Submit your next manuscript to BioMed Central and take full advantage of:}

- Convenient online submission

- Thorough peer review

- No space constraints or color figure charges

- Immediate publication on acceptance

- Inclusion in PubMed, CAS, Scopus and Google Scholar

- Research which is freely available for redistribution 